\title{
Disparity In The Superintendency
}

\author{
Ava J. Muñoz, Texas A\&M University- Commerce, USA \\ Shirley J. Mills, University of Texas-Pan American in Edinburg, USA \\ Anita Pankake, USA \\ Sandra Whaley, University of Texas-Arlington, USA
}

\begin{abstract}
This paper examines the career aspirations of female and male central office administrators and their reasons for or against pursuing a superintendency, in the Texas, $K-12$ public school arena. Information unique to seeking and attaining superintendencies by these central office administrators will be presented, to assist with illuminating gender specific commonalities and differences, between all of the superintendent aspirants, involved in the study. This study provides insight, as to why gender disparity persists in the office of the superintendency, despite the availability of similarly, talented female and male central office administrators who aspire to gain the position of superintendent.
\end{abstract}

Keywords: Career Aspirations; Superintendency; Gender Equity; Central Office Administrators; Disparity

\section{INTRODUCTION}

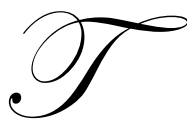

he job of superintendent has become crucial in determining the fate of a school district (Brunner \& Björk, 2001; Kowalski, McCord, Peterson, Young \& Ellerson, 2011). The superintendent initiates, implements and promotes the district's vision towards achieving academic success of all of its students, evaluates student achievement, takes a crucial part in selecting principals, and serves as liaison between the school board and school community (Kamler, 2009). A superintendent must assist in educating the school community and be knowledgeable in regards to all of the educational mandates prescribed by the educational governing boards (Grogan, 2008; Kowalski, et al, 2011; Sherman \& Grogan, 2003).

Brunner (2000) wrote that since its inception in the late 19th century, the position of the superintendency was made up predominantly of white males. This continued on into the 20th century - "More specifically, men occupied from $85 \%$ to $96 \%$ of all superintendencies during this time period" (Tallerico \& Blount, 2004, p. 640). Not much has changed since then. Mertz (2006) affirmed that the lack of women in the superintendency and the "continued scarcity in the position of superintendent, even after 30 years, suggests that the position has been little affected by Title IX and that women continue to have a long, uncertain way to go to reach the top spot" (p. 556). Presently, women hold $24.1 \%$ of the superintendencies, nationwide (Kowalski, et al, 2011).

The purpose of this study was to examine the career aspirations of female and male central office administrators and their reasons in pursuing a superintendency. According to Hayes (2001), "the exodus of superintendents, along with the lack of enthusiasm of most teachers and principals to even seek out the position, almost assures unparalleled opportunities for future candidates" (p. 34). Yet, women continue to serve as superintendents in staggeringly low numbers (Brunner \& Björk, 2001; Gilmour \& Kinsella, 2009; Grogan \& Brunner, 2005; Kamler, 2009; Kowalski, et al, 2011; Mahitivanichcha \& Rorrer, 2006; Mertz, 2006; Skrla, Reyes, \& Scheurich, 2000; Young \& McLeod, 2001). Specifically, this study sought information to address the question: Do female and male central office administrators aspire equally to become superintendents?

In achieving the purpose of this paper, a brief overview of the study design is provided. Data specifically related to the question is presented, followed by a discussion of the meanings these findings might have for creating parity in the number of male and female superintendents. 


\section{DESIGN OF THE STUDY}

The design of the study is mixed methods. According to Creswell (2014), utilizing the mixed methods approach allows for the implementation of both quantitative and qualitative research. The participants were 2018 central office administrators (superintendents, associate, assistant, and deputy superintendents) located in school districts throughout the state of Texas.

\section{INSTRUMENTATION}

The bulk of the information presented in this paper is quantitative and based on responses to an online survey. All but three items on the survey were quantitative. Three of the items were open-ended questions in which respondents were invited to offer comments online through comment boxes. Once all survey data were received, the qualitative method of one-to-one personal interviews was collected.

Invitations to participate in this research by completing an online survey were sent to 2018 central office administrators (superintendents, associate, assistant, and deputy superintendents) located in school districts throughout the state of Texas. The purpose of the survey was to determine whether these central office administrators aspire or have aspired to the superintendency. Subjects were identified using school district websites, Texas Education Agency (TEA) directory information for public school districts, and the Texas Association of School Administrators database (TASA).

\section{DATA ANALYYSIS}

Two hundred and forty-four participants completed and returned the survey. Returned surveys were inputted and tabulated. An analysis of each question was completed using descriptive and inferential statistical methods. For the qualitative component of personal, one-to-one interviews, survey respondents' data was used to group and randomize respondents in order to determine the individuals to be invited. Individual interviews sought to obtain information about the effects of mentoring on central office administrators' (both men and women) career aspirations towards the superintendency.

\section{PRESENTATION OF FINDINGS}

\section{Who Responded?}

Individuals representing each of the job titles used to define central office administrator for this study responded to the online survey. Superintendent was the most common title reported by the respondents. Of the respondents, $49.2 \%$ indicated having the title of superintendent. These 121 respondents were divided by gender ( 21 females and 100 males). The next largest group of respondents by title was assistant superintendents. A total of 92 responses were received, representing approximately $37.7 \%$ of the total. In the assistant superintendent group, the distribution by gender of those who completed the survey was 51 females and 41 males. A complete display of these responses by gender and job title is offered in Table 1 .

Table 1: Frequencies of Survey Respondents According to Job Title and Gender

\begin{tabular}{lccc}
\hline Job title & Females & Males & All participants \\
\hline Asst. Superintendent & 51 & 41 & 92 \\
Assoc. Superintendent & 4 & 9 & 13 \\
Deputy Superintendent & 1 & 1 & 2 \\
Superintendent & 21 & 100 & 121 \\
Other central office position & 7 & 9 & 16 \\
Total \# of participants & $84(34.4 \%)$ & $160(65.6 \%)$ & $244(100 \%)$ \\
\hline
\end{tabular}

Age. The reported ages of the responding group revealed that $73.1 \%$ of the men and $70.6 \%$ of the women were between the ages of 35 and 56 years. More than half of the women $(54.1 \%)$ and 45.6 percent of the men were in the 46 - 56 age range. Twenty-five of the 84 women and 41 of the 160 men in this group identified themselves as 
being in the 57-67 year age category. One of the men and none of the women reported being 68 years of age or older.

Marital status. Ninety-six percent of the male respondents and over $85 \%$ of the female respondents indicated their marital status as married. Overall, 231 of 244 , or $94.7 \%$, of the respondents identified themselves as married. The only other marital status category for both genders was that of divorced. Less than $6 \%$, of both males and females (5.3\%) responded that they were divorced.

Highest degree earned. Six of the 33 respondents, or $12.8 \%$, indicated they had earned a master's degree plus additional hours. Additionally, 122 of the 244 respondents, or $50 \%$, reported having earned a doctoral degree. Of these 122 with doctoral degrees, $67.2 \%$ of the respondents were male and $31.1 \%$ were female.

\section{Reasons For Pursuing A Superintendent's Certificate}

A follow-up to the item requesting information on when the superintendency credential was obtained asked respondents to share why they had pursued a superintendent's certificate. Based on a review of the respondents' answers, three categories or topics emerged: (a) career advancement, (b) salary increase, and (c) student impact.

Career advancement. In this section, responses from females included the following:

- "I was working on my doctorate in educational administration and it was part of my degree plan to add the superintendent's certificate. I also had aspirations to eventually become a superintendent."

- $\quad$ "I had completed all the work necessary for a superintendent's certification while working on my doctorate and wanted to be prepared if the right opening became available."

Responses from males included the following:

- "I wanted to eventually become a superintendent."

- "I knew that eventually I would like to be in a position to administer a school district."

It was observed that female respondents were most likely to augment their educational credentials prior to taking any initiative in applying for a superintendency. Male respondents had a gut feeling; they knew that they wanted to be a superintendent. How they arrived at a superintendency was more a matter of desire than preparation.

Student impact. Responses from females included "I pursued the Superintendent's certification because it is a position where you can help students and teachers the most."

Responses from males included the following:

- $\quad$ "One was the belief that I could impact more students positively from a superintendent's position than a classroom teacher position."

- $\quad$ "Impact as many students' lives as possible to give them the freedom to make logical choices for their life after they shake my hand and receive their diploma..."

Both male and female respondents agreed that the position of superintendent was instrumental to providing positive student intervention on a larger scale.

Salary increase. Only male respondents provided information related to this topic. Responses from males included the following:

- "Better salary for family"

- $\quad$ "I wanted to be a superintendent of a 3A or larger school district. Part of the reason was that I could not afford to raise a family on a teacher's salary." 
Better salary or an increase in salary were factors of importance to male respondents and explained why they pursued a superintendency. Which was not a surprising response, being that "despite that men no longer think they should be the sole breadwinner in the household, they still desire to make more money than their spouses do" (Zuo, 1997, p. 812).

\section{Attaining The Superintendency}

Number of times applied for the superintendency. When participants were asked to indicate the number of times they had applied for a superintendency, over one half (52.9\%) of the female respondents reported they had never applied for this position; this was true for only (18.1\%) of the male respondents. The remaining $81.9 \%$ of male respondents applied for the position of superintendent at least once and 33.8\% indicated they had applied four or more times for a superintendency. Nearly, $45 \%$ of the female participants had applied for a superintendency at least once. Eleven women indicated they had applied for a superintendent's position four or more times. Two of the female respondents chose not to respond to this question.

Number of times interviewed for the superintendency. A follow-up item to the question regarding the number of times participants had applied for a position as superintendent was a request from those who had applied to share how many times they had interviewed for the position. Although almost $82 \%$ of the males had applied for the superintendency, only $74.4 \%$ had been invited for interviews. One hundred and nineteen of the male respondents reported having at least one interview for the superintendency and eight of those males reported experiencing more than 10 such interviews.

Over a third or twenty-nine (34.5\%) of the female respondents reported having participated in 1-3 interviews, whereas, over half, or 56\% (47) female respondents had never applied for the position and therefore could not report having participated in any superintendency related interviews. Seven or less than $10 \%$ had applied 5 or more times. One of the female participants offered no response to this question.

\section{Success In Attaining A Superintendency}

Table 2 indicates that 109 of 244 respondents, or $44.7 \%$, reported never having attained the superintendency. Sixty-eight of the total number of respondents or $27.9 \%$, reported success in attaining the superintendency on one occasion. Thirty-seven of 244 respondents, or $15.2 \%$, reported success in attaining the superintendency on two occasions. Nineteen of 244 respondents, or $7.8 \%$, reported success in attaining the superintendency on three occasions. Ten of 244 respondents, in this case male only, or $4.1 \%$, reported success in attaining the superintendency on four or more occasions. One of the 84 female respondents or $1.2 \%$ did not respond to this question.

Overall, female respondents were successfully attaining a superintendency less than one- third of the time they interviewed for the position. Consequently, male respondents were securing a superintendency at a $70 \%$ success rate.

Table 2: Frequencies And Percentages Of Respondents Attaining The Superintendency By Gender

\begin{tabular}{|c|c|c|c|c|}
\hline \multirow{2}{*}{$\begin{array}{c}\text { Number Of Times } \\
\text { Superintendency } \\
\text { Successfully Attained }\end{array}$} & \multicolumn{2}{|c|}{ Female } & \multicolumn{2}{|c|}{ Male } \\
\hline & Frequency & Percentage & Frequency & Percentage \\
\hline 0 & 56 & 66.7 & 53 & 33.1 \\
\hline 1 & 19 & 22.4 & 49 & 30.6 \\
\hline 2 & 5 & 5.9 & 32 & 20.0 \\
\hline 3 & 3 & 3.5 & 16 & 10.0 \\
\hline $4+$ & 0 & 0.0 & 10 & 6.3 \\
\hline $\mathrm{NR}^{*}$ & 1 & 2.3 & 0 & 0.0 \\
\hline Total & 84 & 100.0 & 160 & 100.0 \\
\hline
\end{tabular}




\section{Year Respondents Will Apply To The Superintendency}

Participants were provided an opportunity to indicate when they anticipated applying for a superintendent's position. One hundred twelve individuals, or $45.9 \%$, did not respond to the question. Of the 112 individuals who did not respond to the "year respondents will apply to the Superintendency" question, $35.7 \%$ were female respondents and $65.3 \%$ were male respondents. Overall, more than half or $52 \%$ of female respondents and $53 \%$ of the male respondents provided no response for this question, conversely indicating that they would not be applying for a superintendency.

\section{Mentoring And Career Aspirations}

Three items on the survey asked respondents for information about mentoring and career aspirations. Two of the items asked if the respondents have or have had a mentor that encouraged or supported their career aspirations. Another question asked the participants to share if they currently serve or have ever served as a mentor who encouraged or supported the career aspirations of others.

Exactly, half (122 of 244) of the respondents indicated that they had a mentor(s) who supported/encouraged their career aspirations. A greater percentage of those respondents reporting they have a mentor were men $(51.9 \%$ male to $45.8 \%$ female). One hundred nineteen of the 244 respondents, or $48.8 \%$, reported that they did not have a mentor(s) who supported/encouraged their career aspirations.

Regarding whether respondents ever had a mentor or sponsor, 76 of 244 (31.1\%) indicated that they had at one time a mentor/sponsor that provided them with career support. Almost 69\% reported not having a mentor/sponsor that provided them with career support.

In reporting on their own activity in the role of mentor, 68 of 244 respondents, or $27.9 \%$, reported serving, now or in the past, in the capacity of mentor. Close to $26 \%$ of the women respondents reported that they have or are serving as a mentor; for men, that percentage was $27.5 \%$.

\section{Reasons For Applying To The Superintendency}

Superintendent respondents were asked to respond to both question 27 (which asked them to rate questions containing criteria which would prove influential in their decision to apply to a superintendency) and 28 (which asked them to rate questions containing criteria which would prove influential in forming their decision not to apply to a superintendency). Central office administrators, other than superintendents, were asked to complete, either question 27 or 28 . A total of 172 respondents completed this survey section using a Likert scale of $1-4(1=$ not important, 2 = somewhat important, 3 = important, 4 = very important). Respondents assigned a numerical value of 1-4 to indicate how important each factor was in their decision to apply for the superintendency. The important (3) and very important (4) responses were combined to determine the mean of importance for each question. Rawls (1998) stated that "these scales were analyzed by computing the mean of each variable and the percentage of respondents who ranked an item as important and very important" (p. 51). The percentage rating was determined by averaging the number of responses indicating important or very important ( 3 and 4 ) assigned by each respondent to each question.

\section{Similarities And Differences Of Groups' Reasons For Applying To The Superintendency}

Amongst the top 4 reasons mentioned for applying to a superintendency, female respondents selected as their top pick "leadership opportunity", while male respondents selected as their top pick "sense of achievement". The second most popular reason female respondents selected to pursue a superintendency was "opportunity for service", while the male respondents elected "salary", as the second most important reason to pursue a superintendency. Female respondents viewed the "opportunity for service" as valuable, when male respondents were focused on "self-development and growth". Lastly, female respondents elected "sense of achievement" rather than "leadership opportunity", as their fourth reason to pursue a superintendency. 
Although both the female group and the male group assigned different values of importance to reasons for applying to the superintendency, three of the most frequently selected reasons for applying to the superintendency by both groups were: (a) leadership opportunity, (b) sense of achievement, and (c) self-development and growth.

Table 3: Similarities and Differences of Groups' Reasons for Applying to the Superintendency (Importance of Factors)

\begin{tabular}{lll}
\hline \multicolumn{1}{c}{ Female } & \multicolumn{1}{c}{ Mmportance } \\
$\begin{array}{l}\text { 1. *Leadership opportunity } \\
\text { 1. *Self-development and growth }\end{array}$ & & 1. *Sense of achievement \\
1. Opportunity for service & & 3. *Self-development and growth \\
2. *Sense of achievement & 4. *Leadership opportunity \\
3. *Salary & \\
4. Mentoring opportunities & \\
\hline *indicates reasons common to both groups & \\
\hline
\end{tabular}

\section{FINDINGS AND DISCUSSIONS OF RESULTS}

The purpose of the survey was to determine whether central office administrators aspire or have aspired to the superintendency. Specifically, this study sought information that would address the question: Do female and male central office administrators aspire equally to become superintendents? Respondents were able to provide interesting information focused on the aspirations of men and women to the position superintendent of schools.

Based on the information from this group of 244 respondents, males appear to be more interested in attaining the superintendency than do females. Fewer women than men in this group indicated that they had obtained the superintendent credential. Findings indicated that women were more likely to apply late in their careers; $34.1 \%$ of those responding affirmatively to this question were applying for the superintendency, at a later date. It would appear that in this study female central office administrators are not attaining superintendencies because they are not applying for them. This, in turn, can be interpreted as indicating these central office women do not aspire to become superintendents. Reinforcing this, more than half $(52.0 \%)$ of all women respondents, when asked "what year they anticipated applying to the superintendency", chose not to respond.

All but 15 of the 160 or $94 \%$ of the male respondents indicated they held a superintendent certificate. The majority of the men among these respondents had applied for the superintendency numerous times. Nearly, $40 \%$ of the males in this group indicated they would begin applying for superintendency within a two year timeframe, with $20.0 \%$ applying in within the year or the following year. Men apply early on in their careers and more frequently; 32 of the 160 or $20 \%$ were applying within 6 to 12 months of completing the survey and $74.4 \%$ had interviewed 1 10 or more times. Men were most specifically concerned with sense of achievement and salary.

The men and women responding to this survey, thus far, mirror many of the characteristics of male and female educational administrators reported in the literature. Based on the respondents' information, both males and females have attained central office positions, however, more males hold the position of superintendent than do females. This is the case across the state of Texas and across the nation; although both males and females attain positions as central office administrators, the vast majority of superintendents are males (Glass \& Franceschini, 2007; Kowalski, et al, 2011).

The top reasons for applying to a superintendency selected by both male and female participants were found to be numerically varied. The two reasons identified as important by male respondents for applying to the superintendency were: (a) sense of achievement, and (b) salary. Additionally, female respondents included (a) selfdevelopment and growth, (b) leadership opportunity, and (c) opportunity for service in their top three reasons for applying.

Although, data from this study indicates that mentoring of women and by women is more frequent than the literature would indicate. The literature continues to address the lack of mentoring for women as a source for some of the delays or barriers for women pursuing the superintendency. Based on the data in this study, more than half of 
males, $51.9 \%$, and nearly $45.8 \%$ of females reported having had a mentor or sponsor. On the other hand, $46.8 \%$ (49.4\% of males and $41.2 \%$ of females) of the respondents reported that they themselves were serving or had served as a mentor or sponsor for someone else.

Mentoring by women for women was absent at the superintendency level due to the lack of superintendencies held by women. This is important because mentors many times act as go betweens among superintendent candidates and school boards. Hodgins and Brooks (2005) stated "women need mentors, role models, and networks of support to be successful in leadership roles previously barred to them" (p. 23). Dana and Bourisaw (2006) affirmed that the "evidence is clear that women who have mentors move into school district or school leadership positions sooner than those who are without mentors" (p. 195). Glass (2000) added that women also seem to have a less developed mentoring system compared to men. "Because women fear asking...likely a result of their cultural upbringing and conditioning... and often are not even aware of how beneficial the efforts to acquire sponsors are, their pathways to reaching a desired superintendency are not quite as smooth...." (Dana \& Bourisaw, 2006, p. 188). We cannot only be content looking at the success of women in gaining a superintendency. We must also ensure that they successfully fulfill the duties and responsibilities of that position (Kamler, 2009). Additionally, "ongoing support for women who have secured the superintendency is also crucial for their continued growth and development as well as their ability to cope with the stresses of the position" (Kamler, 2009, p. 143).

\section{SUMMARY}

A vast amount of insight was obtained by examining both groups' of participants and identifying commonalities and differences regarding their superintendency aspirations. Taking into account the impending shortage of school leaders, it is critical to the success of our schools that all educators be provided the opportunity to work in the capacity they are the most qualified for, regardless of gender. According to Kowalski, et al, (2011), "with only about half, 51\%" of the nation's superintendents considering retirement, "this leadership vacuum looms as a critical issue for school boards-especially those in big city districts, where superintendents often serve for less than three years" (Quinn, 2005, p. 46). Numerous school districts throughout the nation are seeking capable leaders to head their school systems (Manuel \& Slate, 2003). It is crucial to discover what is causing well-qualified educators not to pursue or being overlooked for the superintendency (Polka \& Litchka, 2008). Kamler (2009) posed that "although there has been a dramatic increase in the number of women candidates for the superintendency, people of color remain few.

The data from this study indicated that the majority of female respondents were not attempting to gain a superintendency. They were remiss in pinpointing, via response, when they would ever apply for a superintendency. So, how do we instill in the female respondents to pursue a superintendency? It would appear that continued mentoring of as well as advocacy for qualified school leaders from these underrepresented groups are necessary to promote their candidacy and, in so doing, may alter the perception that there is a shortage of candidates" (p. 143). Regardless of gender, mentoring was seen as extremely influential in the progression of all the interview participants' eventual career path choices (Glass \& Franceschini, 2007). Unfortunately, slightly less than one third of all respondents (30.6\%) indicated that they had at one time received career mentoring/support. Because mentoring is viewed as critical for women's access into a superintendency, the lack of mentoring appears to severely limit a woman's possibilities of receiving mentoring into a superintendency position, thereby curtailing the career trajectory of women.

It is critical to the success of the nation's schools that all educators be afforded the opportunity to work in the capacity they are the most qualified for, regardless of gender. Mentoring is urgently needed to provide disconnected male and female central office administrators with critical information exclusive to the superintendency (Brunner \& Grogan, 2007; Edson, 1988; Kowalski, et al, 2011). It is possible that through the acquisition of mentors (Gardiner, Enomoto, \& Grogan, 2000) and their connections, there might be an increase in the number of female superintendents, consequently producing the opportunity to level the superintendency playing field for everyone. 


\section{AUTHOR INFORMATION}

Dr. Ava J. Muñoz is currently an Assistant Professor in the Educational Leadership Department at Texas A\&M University-Commerce in Commerce, Texas. She received her Doctorate in Educational Leadership from the University of Texas-Pan American. A former elementary school administrator and teacher, Muñoz currently teaches graduate classes in Diversity, Ethics and School Organization. Her research interests include gender equity, diversity, social justice, bilingual education and school leadership. E-mail: ava.munoz@tamuc.edu (Corresponding author)

Dr. Shirley J. Mills is currently an Associate Professor in the Educational Leadership Department at the University of Texas-Pan American in Edinburg, Texas. She received her Ph.D. from the University of Nebraska-Lincoln in Educational Leadership and Higher Education. A former elementary school teacher, Mills teaches Curriculum Development and Organizational Leadership graduate level courses. Her research interests include gender equity, women's studies, teacher education and the school leadership.

E-mail: millssj@utpa.edu

Dr. Anita Pankake is a retired professor, former doctoral program director and department head and past interim associate dean for research and graduate studies. She has taught Educational Leadership graduate courses at several Texas universities (University of Texas-Pan American, Texas A\&M University-Commerce and Texas Tech University), Kansas State University and Southern Illinois University. Pankake holds a doctorate in Educational Administration and Supervision from Loyola University of Chicago. A former school teacher and administrator, she has taught courses in Leadership, Organizational Theory, Organizational Change, The Principalship and School Administration. Pankake's research interests include gender equity, women's studies, professional learning communities and the equitable school leadership.

E-mail: pancake@sbcglobal.net

Ms. Sandra Whaley is a doctoral candidate at the University of Texas-Arlington in Arlington, Texas. Whaley works in a public school system in the north Texas area. During her doctoral program studies, she served in the capacity of Research Assistant. E-mail: sandra.whaley@mavs.uta.edu

\section{REFERENCES}

1. Brunner, C. C. (2000). Principles of power: Women superintendents and the riddle of the heart. Albany, NY: State

2. University of New York Press.

3. Brunner, C. C., \& Björk, L. G. (Eds.). (2001). The new superintendency. New York, NY: Elsevier Science.

4. Brunner, C. C., \& Grogan, M. (2007). Women leading school systems: Uncommon roads to fulfillment. Lanham, MD: Rowman and Littlefield Education.

5. Brunner, C.C. (2008). Invisible, limited, and emerging discourse: Research practices that restrict and/or increase access for women and persons of color to the superintendency, 18(6), 661-662.

6. Creswell, J. W. (2014). Research design: Qualitative, quantitative, and mixed methods approaches (4th ed.). Thousand Oaks, CA: Sage.

7. Dana, J. A., \& Bourisaw, D. M. (2006). Women in the superintendency: Discarded leadership. Lanham, MD: Rowman and Littlefield Education.

8. Edson, S. K. (1988). Pushing the limits: The female administrative aspirant. Albany, NY: State University of New York Press.

9. Gardiner, M. E., Enomoto, E., \& Grogan, M. (2000). Coloring outside the lines: Mentoring women into school leadership. Albany, NY: State University of New York Press.

10. Gilmour, S. L., \& Kinsella, M. P. (2009). Succeeding as a female superintendent: How to get there and stay there. Lanham, MD: Rowman and Littlefield Education.

11. Glass, T. E. (2000). Where are all the women superintendents? The School Administrator, 6(57), 28-32. Retrieved from http://findarticles.com/p/articles/mi_m0JSD/is_6_57/ai_77336323/pg_4/?tag=content;col1

12. Glass, T. E., \& Franceschini, L. A. (2007). The state of the American school superintendency: A middecade study. Lanham, MD: Rowman and Littlefield Education. 
13. Grogan, M., \& Brunner, C. C. (2005). Women leading systems: Latest facts and figures on women and the superintendency. The School Administrator, 2(62), 46-50.

14. Grogan, M. (2008). The short tenure of a woman superintendent: A clash of gender and politics. Journal of School Leadership, 18(6), 634-660.

15. Hayes, W. (2001). So you want to be a superintendent? Lanham, MD: Scarecrow Press.

16. Hodgins, D., \& Brooks, J. S. (2005, November). Paradigm shift or paradigm stasis? An analysis of research on women in educational leadership from 1980 to 2004. Paper presented at the 2005 Annual Convention of the University Council for Educational Administration, Nashville, TN.

17. Kamler, E. (2009). Decade of difference (1995-2005): An examination of the superintendent search consultants' process on Long Island. Educational Administration Quarterly, 45(1), 115-144. doi:10.1177/0013161X08327547

18. Kowalski, T.J., McCord, R.S., Petersen, G. J., Young, I.P. \& Ellerson, N.M. (2011). The American school superintendent [Kindle DX version]. Retrieved from Amazon.com

19. Mahitivanichcha, K., \& Rorrer, A. K. (2006). Women's choices within market constraints: Re-visioning access to and participation in the superintendency. Educational Administration Quarterly, 42(4), 483-517. doi:10.1177/0013161X06289962

20. Manuel, M. A., \& Slate, J. R. (2003) Hispanic female superintendents in America: A profile. Advancing Women in Leadership. Retrieved from http://www.advancingwomen.com/awl/winter2003/MANUEL 1.html

21. Mertz, N. T. (2006). The promise of Title IX: Longitudinal study of gender in urban school administration, 1972 to 2002. Urban Education, 41(6), 544-559. doi:10.1177/0042085906292511

22. Polka, W. S., \& Litchka, P. R. (2008). The dark side of educational leadership: Superintendents and the professional victim syndrome. Lanham, MD: Rowman and Littlefield Education.

23. Rawls, S. L. (1998). Career aspirations: A study of superintendent certificate holders in Washington State in 1997. Unpublished manuscript, Washington State University, Pullman, WA.

24. Quinn, T. (2005). Plan to succeed. American School Board Journal, 192(4), 46-49.

25. Sherman, W. H., \& Grogan, M. (2003). Superintendents' responses to the achievement gap: An ethical critique. International Journal of Leadership in Education, 6(3), 223-237.

doi:10.1080/1360312032000090073

26. Skrla, L., Reyes, P., \& Scheurich, J. J. (2000). Sexism, silence, and solutions: Women superintendents speak up and speak out. Educational Administration Quarterly, 36(1), 44-75. doi:10.1177/00131610021968895

27. Tallerico, M., \& Blount, J. M. (2004). Women and the superintendency: Insights from theory and history. Educational Administration Quarterly, 40(5), 633-662. doi:10.1177/0013161X04268837

28. Young, M. D., \& McLeod, S. (2001). Flukes, opportunities, and planned interventions: Factors affecting women's decisions to become school administrators. Educational Administration Quarterly, 37(4), 462502. doi:10.1177/00131610121969398

29. Zuo, J. (1987). The effect of men's breadwinner status on their changing gender beliefs. Sex Roles,37 (910), 799-816. 
NOTES 